\title{
Characterization of Microorganism Isolated From "Fermege": The Ruminant Fermented Feed from Water Hyacinth (Eichhornia crassipes)
}

\author{
Isnawati $^{1}$, Guntur Trimulyono ${ }^{2}$ \\ Department of Biology \\ Universitas Negeri Surabaya \\ Surabaya, Indonesia \\ 1isnawati@unesa.ac.id, 20unturtrimulyono@unesa.ac.id
}

\begin{abstract}
The aim of this study was to determine the number of bacteria and fungi in the fermentation process and characterization of these microorganisms. There were several steps in this research including production of fermented feed, isolation of indigenous microorganisms, purification, characterization of microorganisms, species identification and test of cellulolytic activity. Results showed that eight bacteria and four fungi indigenous from the fermented feed were isolated. The species were Bacillus badius, B. subtilis, B. brevis, B. pumilus, B. cereus, Xenorhabdus luminescent, Pseudomonas stutzeri and $\mathbf{P}$. diminuta. In addition, the species of fungi were Aspergillus niger, A. flavus, Mucor sp. and Cunninghamella sp. All of isolates shown the excellent cellulolytic activity. Aspergillus niger, Cunninghamella sp., B. brevis, B. cereus, and P. diminuta showed the best celulolytic activity. We recommend the use of microorganisms in the manufacture of cellulose fermentation starter component of the formula for producing ruminant feeds.
\end{abstract}

Keywords - water hyacinth; celullotic degradation; celluloyti bacteria; celullolytic fungi; fermented feed production

\section{INTRODUCTION}

Water hyacinth (Eichhornia crassipes) included in perennial aquatic herb or the aquatic weed. The water hyacinth (Eichhornia crassipes) is the most successful colonizers in the plant world. This free-floating freshwater plant has spread from tropical South America [9]. Water hyacinth has high rate multiplication. Water hyacinth has a long roots which are commonly suspended in water. The abilities of water hyacinth are higher growth rate, pollutant absorption efficiency, and renewability shows that using this plant can be considered as a suitable technology for the treatment of wastewater [8]. The structure of aquatic plants root in particular water hyacinth can present suitable environment for the aerobic microorganisms to function in the sewage system [6].Water hyacinth can grow very rapid and float on the water surface. The growth is very difficult to control. There are many problems that occur due to the uncontrolled growth of water hyacinth such as covering the surface of water affecting on decreasing biodiversity, evaporating water rapidly and microhabitat for disease vectors [1].

Consequently, some efforts should be made to prevent environmental damage that caused the plant. The water hyacinth has been used as a phytoremediation agent [5]. Water hyacinth is possible to become feed fermented because of the high nutrient content. Water Hyacinth dry material contains crude protein $(10,1-11,2 \mathrm{~g} / 100 \mathrm{~g})$, crude fibre $(26,1-27,4$ $\mathrm{g} / 100 \mathrm{~g})$, ash (12,3 -12,4 g/100g), and energy 1999,7-2054,1 $\mathrm{Kcal} / \mathrm{kg}$. According to [5] water hyacinth has more advantages impact in environment and human health such as biogas, production of animal feed and compost Also, feeded goat by fermented water hyacinth showed an increased level of body weight [4]. Moreover, the lamb analysis showed that the lamb of the goat feed with fermented water hyacinth had high protein and low-fat [7].

The fermentation process is essential to be applied in the feed production in order to the feed produced that contains high nutrient. The feed had a good level of digestibility and palatability. The report found that fermentation period as long as six weeks using Aspergillus niger shown the best result. In this process, Aspergillus niger is a probiotic. The addition of probiotics accelerates and enhance the fermentation process [3] [4]. Probiotics are living microorganisms that can improve the health and physiological benefits when consumed. The mixture of the microorganism as probiotic more advantageous than the using of a single microorganism.

Fermentation process always involves microorganisms like bacteria and fungi. The speed of fermentation process depends on several parameters such as the suitability of the type of microbes that work in the fermentation process, and chemical and physical conditions. Therefore, it needs to isolate specific inoculum [2]. Fermentation process associated to enzymes that belong to the microbes.

Water Hyacinth contains high amount of cellulose. Water Hyacinth has a high percentage of cellulose and hemicellulose (44\% to $66,9 \%$ of dry weight basis) and low component of lignin from $3.5 \%$ to $9.5 \%$. The content of water hyacinth is sufficent to extract fermentable sugars. The presence of lignin can make it resistant to degradation due to compact structure between cellulose and hemicelluloses [6]. These microorganisms are unique in terms of their diversity and properties. Based on the facts, each substance naturally has different indigenous microorganisms from other ingredients. The isolates were used as starter formulation that are expected to accelerate the fermentation process. This study carried out 
the isolation, characterization and cellulolytic activity of bacteria and fungi that were contained in the fermented feed made from water hyacinth.

\section{MATERIALS AND METHODS}

Isolation procedures of indigenous microorganisms in the water hyacinth compost that capable to degrade of cellulose was performed using the following steps. Composting of water hyacinth was taken $10 \mathrm{~g}$ and was suspended in $90 \mathrm{~mL}$ of sterile water. This suspension was shaken at $150 \mathrm{rpm}$ for 30 min at $30^{\circ} \mathrm{C}$. Then the technique of dilution rank minus ten to seven series $\left(10^{-7}\right)$ dilution was performed. The suspension of the $10^{-7}$ dilution was taken as $100 \mu \mathrm{L}$ and was stocked in the salt medium $\left(\mathrm{NaNO}_{3} 0,5 \mathrm{gL}^{-1} ; \mathrm{K}_{2} \mathrm{HPO}_{4} 1 \mathrm{gL}^{-1} ; \mathrm{MgSO}_{4} .7 \mathrm{H}_{2} \mathrm{O}\right.$ $0,5 \mathrm{gL}^{-1} ; \mathrm{FeSO}_{4} .7 \mathrm{H}_{2} \mathrm{O} 0,02 \mathrm{gL}^{-1} ; \mathrm{KCl} 0,2 \mathrm{gL}^{-1}$ and that $20 \mathrm{gL}^{-1}$ was set at $\mathrm{pH} 7.5$, the media was enriched with $0.05 \%$ (w/v) AZCL HE-Cellulose (Megazyme, Bray, Ireland) as the single carbon source. Furthermore, the incubation was carried out at $35^{\circ} \mathrm{C}$ for 7 days. The colonies of bacteria that can degrade cellulose will be surrounded by a blue zone. This indicated of their cellulase enzyme activity in the medium in a petri dish. Each colony that was surroundedblue zone was isolated and was subcultured to medium Trypto-Soya Agar (TSA; Nissui Pharmaceutical, Tokyo, Japan), as pure culture.

Similarly, the isolation of fungi with the cellulase enzyme activity was done using bacterial isolation, except its media composition. Isolation of fungi in order to getpure culture was performed in the three different kinds of media, MEA (malt extract agar), PDA (potato dextrose agar) and CA (Czapek's agar). The fungi with cellulase activities was determined by plate method screening on medium (PSM) using a solution that contain Mendel's mineral salt like following composition, urea $0.3 \mathrm{gL}^{-1} ;\left(\mathrm{NH}_{4}\right)_{2}\left(\mathrm{SO}_{4}\right) 1.4 \mathrm{gL}^{-1} ; \mathrm{KH}_{2} \mathrm{PO}_{4} 0.2 \mathrm{gL}^{-1} ; \mathrm{CaCl}_{2}$ $0.3 \mathrm{gL}^{-1} ; \mathrm{MgSO}_{4} 0.3 \mathrm{gL}^{-1}$; yeast extract $0.25 \mathrm{gL}^{-1}$; and protease peptone $0.75 \mathrm{gL}^{-1}$ with CMC (carboxymethyl cellulose) 10 $\mathrm{gL}^{1}$ and to be $17.5 \mathrm{gL}^{-1}$. After few weeks, the fungi that fungi were incubated at a temperature of $25^{\circ} \mathrm{C}\left( \pm 2^{\circ} \mathrm{C}\right)$ for 7 days. Fungi with cellulolytic activity will be characterized by the hydrolysis zone around it. For a more visible and easier to observe, the medium was colored with $1 \%$ Congo Red dyes for 30 minutes, and was washed with $1 \mathrm{M} \mathrm{NaCl}$ for 20 minutes.

The pure isolates of bacteriawere characterized in terms some kinds of the character of the colony like Gram stain, motility observation, catalase enzyme activity. The Microbact Identification Kits (Microbact ${ }^{\mathrm{TM}}$ GNB 12A dan 12B) were used in this research. The pure isolates of fungi were characterized by morphological observation using microscopeof the colony, hypha, color and shape of the spore.

\section{RESULTS}

The number of bacteria that was obtained in this study is shown in Table 1. Based on the result, it can be stated that bacteria in a fermentation process of water hyacinth that contained eight isolates. Regarding the character of optical view, it was dominated by translucent colonies (4 colonies), the colony with opaque optical character ( 3 colonies), and the transparent colony (1 colony). Regarding the character of surface view, there are 4 colonies with a smooth shiny surface, not shiny smooth (3 colonies) and the colony with a rough surface ( 1 colony). Most colonies of white ( 7 colonies) and only one colony that is not pigmented (transparent). There were four kinds of colonies have the irregular shape, rhizoid shape 2 colonies, a circular shape one colony and filamentous one colony also. There are 3 kinds of elevation colonies were raised as much as 5 colonies, convex 2 colonies, and flat 1 colony. There are 5 different forms edges of colonies were filamentous as many as 2 colonies, lobat 2 colonies, undulate one colony, two entire colonies and erode one colony.

In addition to the characteristics of the colony in this study, isolates were observed the cell characteristics. The first as the form of the cell. By simple staining it was got several forms of cells namely streptobacilli, streptococci, monococcus, staphylococcus, and monobacillus. Based on gram staining, there were 6 isolates was gram-positive and gram -negative was 2 isolates. On the examination of the motility of isolates were obtained 5 isolates motile and non-motile 3 isolates. All isolates showed positive catalase activity.

Bacteria species in this research was shown in Table 2. Based on Table 2, there were eight bacteria species that was found in the fermented feed that was made from water hyacinth. These bacteria species were Bacillus badius, $B$. subtilis, B. brevis, B. pumilus, B. cereus, Xenorhabdus luminescens, Pseudomonas stutzeri and $P$. diminuta. In addition, the fungi that are found in this research is displayed in the following Table 3. Based on Table 3 there were four kinds of the fungi species in the fermented feed. They are Aspergillus niger, A. flavus, Mucor sp. and Cunninghamella sp.

TABLE III. IDENTIFICATION FUNGI INDIGENOUS FROM WATER HYACINTH

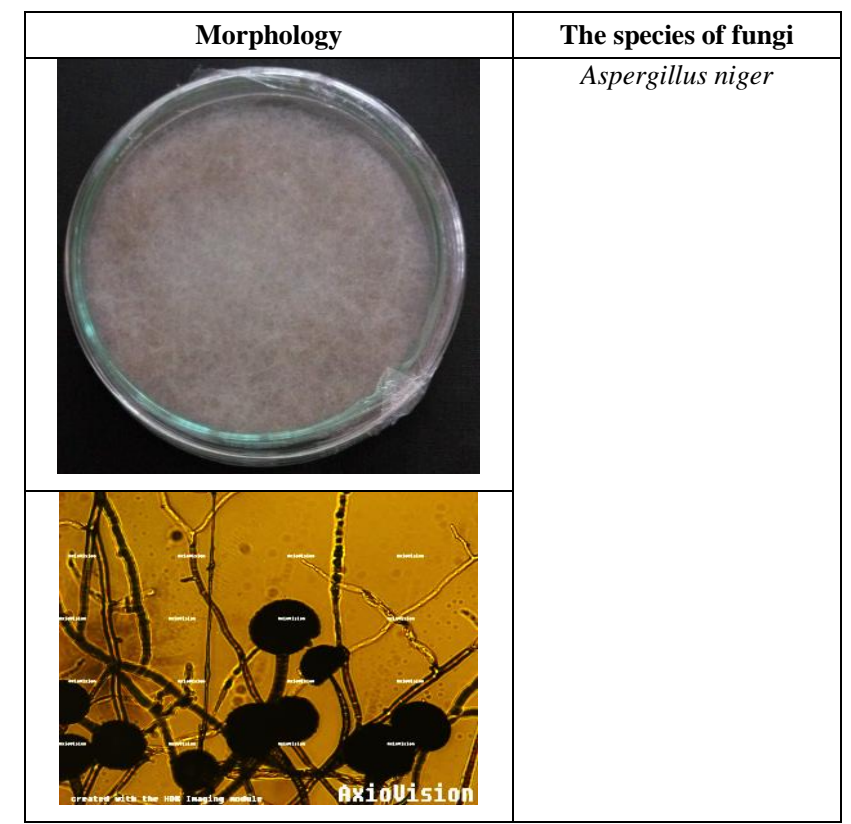




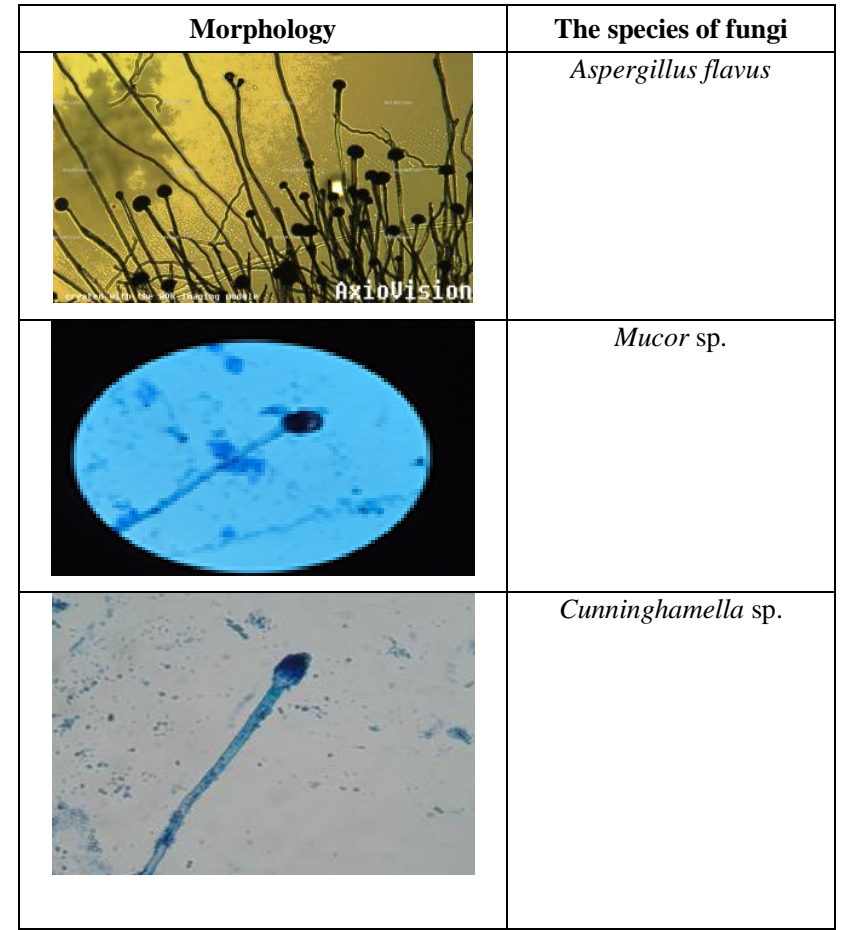

All of indigenous bacteria in this fermented feed have cellulolytic activity. Based on the Figure 1, there were three species of bacteria that had high cellulolytic activity, namely $B$. brevis, B. cereus, and $P$. diminuta. Based on the Figure 2 there were two species of fungi that had high cellulolytic activity, namely Aspergillus niger and Cunninghamella sp.

\section{DISCUSSION}

Cellulase was a complex enzyme that contains at least three kinds of enzymes so that the cellulose was contained in the raw material can be perfectly digested into glucose. Glucose is a simple organic compounds or nutrients that can be absorbed by the digestive system of ruminants. The third group of enzymes found in the cellulase enzyme complex were exoglucanase, endoglucanase, and beta-glucosidase [6]. Exoglucanase and endoglucanase digest chain of glucose, whereas beta-glucosidase was cut to completely digestion residues into short glucose chain, as a result of cellulose digestion perfectly.

The more variations cellulolytic bacterial species involved in fermentation process, the faster of fermentation process takes place [3][4]. The more variations of bacteria, the greater number of enzymes involved in the fermentation process or by way between these bacteria work synergistically. Some investigators known as the species of Bacillus can degrade cellulose, based on the its capacity to use carboxymethylcellulose (CMC) as single carbon sourcein laboratory culture. Water hyacinth is cellulosic materials, because of its cellulose. Besides that, there is a Bacillus species as indigenous microorganisms in this plant.Xenorhabdus poinari is the cellulolytic bacteria in the gut of three different phytophagous insects, Oxyavelox belonging to order orthoptera and Propylea quatu urdecimpunctata and Aspidomor phamiliaris both belonging to order coleopteran . Indigenous bacteria in water hyacinth in this research were identified as Xenorhabdus luminescent.Indigenous bacteria Pseudomonas spp. found in Mahanadi River Delta were identified as cellulolitic bacteria. Cellulolitic activity of this bacteria like Pseudomonas stutzeri and $P$. diminuta were found in this research.

Aspergillus niger is a kind of fungi that has role as the cellulase source. Cellulase production by Aspergillus niger under submerged and solid state fermentation was done with kinds of substrate like coir waste and agricultural residue like finger millet hulls, sorghum hulls, soybean hulls, groundnut husk, banana peels, corn stalk, cassava peels, sugarcane bagasse, saw dust, rice straw and sheanut cake. The substrates used by Aspergillus niger to produce cellulase contain cellulose and the fact indicate that Aspergilus niger have cellulolitic activity. In the water hyacinth, Aspergillus niger and A. flavus found as indigenous microrganism because of its cellulolitic activity.

\section{CONCLUSION}

In this study water hyacinth has a high percentage of cellulose and hemicellulose and low component of lignin. It were eight isolates of bacteria and four isolates of fungi with the variation of cell and colonies characteristics have been found. The bacteria species were Bacillus badius, B. subtilis, B. brevis, B. pumilus, B. cereus, Xenorhabdus luminescens, Pseudomonas stutzeri and $P$. diminuta while the fungi species were Aspergillus niger, A. flavus, Mucor sp. And Cunninghamella sp. Among bacteria species that found in this research, B. brevis, B. cereus, and $P$. diminuta show high celulolytic activity. Aspergillus niger and Cunninghamella sp. were fungi that had high cellulolytic activity.

\section{REFERENCES}

[1] H. Abral, D. Kadriadi, A. Rodianus, P. Mastariyanto, Ilhamdi, S. Arief, S.M. Sapuan, R.I. Mohamad, "Mechanical properties of water hyacinth fibers - Polyester composites before and after immersion in water," Mater. Des., vol. 58, pp. 125-129, 2014.

[2] I.Z. Boboescu, M. Ilie, V.D. Gherman, I. Mirel, B. Pap, A. Negrea ÉvaKondorosi, TiborBíró, and GergelyMaróti, 2014, "Revealing the factors influencing a fermentative biohydrogen production process using industrial wastewater as fermentation substrate" Published online 2014 Sep 24. doi: 10.1186/s13068-014-0139-1, PMCID: PMC4177422.

[3] H. Fitrihidajati, Isnawati, dan G. Suparno. Pemanfaatan Eceng Gondok (Eichornia crassipes) untuk Pakan Ternak Ruminansia sebagai Salah Satu Cara Mengatasi Gulma Perairan, Laporan Penelitian Hibah Bersaing, Universitas Negeri Surabaya, 2013.

[4] H. Fitrihidajati, Isnawati dan G. Suparno. Pemanfaatan Eceng Gondok (Eichornia crassipes) untuk Pakan Ternak Ruminansia sebagai Salah Satu Cara Mengatasi Gulma Perairan, Laporan Penelitian Hibah Bersaing Lanjutan, Universitas Negeri Surabaya, 2014.

[5] L.S. Koutika, and H.J. Rainey "A Review of the Invasive, Biological and Beneficial Characteristics of Aquatic Species Eichornia Crassipes and Salvinia Molesta," Appl. Eco. Environ. Res. vol. 13, pp. 263-275, 2015.

[6] S. Rezania, P. Mohanadoss, T. Amirreza, E.M. Shaza, F.M. Mohd, M.T Shazwin, S. Farzaneh, M.S. Fadzlin, "Perspectives of phytoremediation using water hyacinth for removal of heavy metals, organic and inorganic pollutants in wastewater," J. environ. Manag., vol. 163, pp. 125-133, 2015 . 
[7] G. Suparno, H. Fitrihidajati dan Isnawati, Pemanfaatan Eceng Gondok (Eichornia crassipes) untuk Pakan Ternak Ruminansia sebagai Salah Satu Cara Mengatasi Gulma Perairan, Laporan Penelitia Hibah Bersaing, Universitas Negeri Surabaya, 2015.
[8] Tham, and H. Thanh, "Water Hyacinth (Eichhornia crassipes)-Biomass Production, Ensilability and Feeding Value to Growing Cattle" Doctoral Thesis, Swedish University of Agricultural Sciences, Uppsala, 2012.

[9] C.B. Wolverton, and R.C. McDonald, "The water hyacinth: From prolific pest to potential provider, $R$. Swed. Acad. Sci. vol. 8, pp. 1-9, 2013

\section{APPENDIX}

TABLE I. INDIGENOUS BACTERIALS CHARACTERS FROM WATER HYACINTH

\begin{tabular}{|c|c|c|c|c|c|c|c|c|}
\hline \multirow{3}{*}{ Characters } & \multicolumn{8}{|c|}{ Isolate sample } \\
\hline & $P 1$ & $P 2$ & $P 3$ & $P 4$ & $P 5$ & P6 & $P 7$ & $P 8$ \\
\hline & $\begin{array}{c}\text { Bacillus } \\
\text { badius }\end{array}$ & $\begin{array}{l}\text { Bacillus } \\
\text { subtilis }\end{array}$ & $\begin{array}{c}\text { Bacillus } \\
\text { brevis }\end{array}$ & $\begin{array}{l}\text { Bacillus } \\
\text { pumilus }\end{array}$ & $\begin{array}{l}\text { Xenorhapdus } \\
\text { luminescens }\end{array}$ & $\begin{array}{c}\text { Bacillus } \\
\text { cereus }\end{array}$ & $\begin{array}{c}\text { Pseudomonas } \\
\text { stutzeri }\end{array}$ & $\begin{array}{c}\text { Pseudomonas } \\
\text { diminuta }\end{array}$ \\
\hline Oxidase & + & + & + & + & - & - & + & + \\
\hline Motilitas & + & + & + & + & + & + & + & + \\
\hline Nitrate & + & + & + & + & - & + & + & + \\
\hline Lysine & + & + & + & + & - & - & - & - \\
\hline Ornithine & - & + & - & + & - & - & - & - \\
\hline $\mathrm{H}_{2} \mathrm{~S}$ & - & - & - & - & - & - & - & - \\
\hline Glucose & - & + & - & + & - & - & - & - \\
\hline Mannitol & - & + & - & + & - & - & - & - \\
\hline Xylose & + & + & - & + & - & - & - & - \\
\hline ONPG & + & + & + & + & + & + & + & + \\
\hline Indole & - & - & - & - & - & - & - & - \\
\hline Urease & - & - & - & - & + & - & + & - \\
\hline VP & + & - & - & + & + & + & - & - \\
\hline Citrate & - & + & + & + & - & - & - & - \\
\hline TDA & - & - & - & + & - & - & - & - \\
\hline Gelatin & + & + & + & - & + & + & + & + \\
\hline Malonate & - & - & - & + & + & - & - & - \\
\hline Inositol & - & - & - & - & - & - & - & - \\
\hline Sorbitol & - & - & - & - & - & - & - & - \\
\hline Rhamnose & - & - & - & - & - & - & - & - \\
\hline Sucrose & - & - & - & - & - & - & - & - \\
\hline Lactose & - & - & - & - & - & - & - & - \\
\hline Arabinose & - & - & - & - & - & - & - & - \\
\hline Adonitol & - & - & - & - & - & - & - & - \\
\hline Raffinose & - & - & - & - & - & - & - & - \\
\hline Salicin & - & - & - & - & - & - & - & - \\
\hline Arginine & + & - & - & - & - & - & - & - \\
\hline Gram's stain & + & - & - & - & - & - & - & - \\
\hline Form & + & + & + & + & + & + & + & - \\
\hline
\end{tabular}


TABLE II. BACTERIALS CHARACTERIZATION AND IDENTIFICATION

\begin{tabular}{|c|c|c|c|c|c|c|c|c|c|c|}
\hline \multirow{2}{*}{$\begin{array}{l}\text { Isolate } \\
\text { Code }\end{array}$} & \multicolumn{6}{|c|}{ Morphology of Colony } & \multicolumn{4}{|c|}{ Morphology of Cell } \\
\hline & $\begin{array}{c}\text { Optical } \\
\text { View }\end{array}$ & $\begin{array}{c}\text { Surface } \\
\text { View }\end{array}$ & $\begin{array}{c}\text { Pigmen- } \\
\text { tation }\end{array}$ & Form & Eleva-tion & ledges colony & $\begin{array}{c}\text { Simple } \\
\text { stain }\end{array}$ & $\begin{array}{c}\text { Gram's } \\
\text { stain }\end{array}$ & Moti-lity & $\begin{array}{c}\text { Cata-lase } \\
\text { Acti-vity }\end{array}$ \\
\hline P1 & Transparent & Rough & $\begin{array}{c}\text { No pigmen- } \\
\text { tation }\end{array}$ & $\begin{array}{c}\text { Fila- } \\
\text { mentous }\end{array}$ & Raised & Filamentous & $\begin{array}{l}\text { Strepto- } \\
\text { bacillus }\end{array}$ & Positive & $\begin{array}{l}\text { Non } \\
\text { motil }\end{array}$ & Positive \\
\hline $\mathrm{P} 2$ & Translucent & $\begin{array}{c}\text { Smooth } \\
\text { dull }\end{array}$ & White & Irregular & Raised & Lobate & $\begin{array}{l}\text { Strepto- } \\
\text { coccus }\end{array}$ & Positive & Motil & Positive \\
\hline P3 & Opaque & $\begin{array}{c}\text { Smooth } \\
\text { dull }\end{array}$ & White & Irregular & Flat & Lobate & $\begin{array}{l}\text { Strepto- } \\
\text { bacillus }\end{array}$ & Positive & $\begin{array}{l}\text { Non } \\
\text { motil }\end{array}$ & Positive \\
\hline $\mathrm{P} 4$ & Opaque & $\begin{array}{c}\text { Smooth } \\
\text { shiny }\end{array}$ & White & Irregular & Convex & Undulate & $\begin{array}{l}\text { Mono- } \\
\text { cocus }\end{array}$ & Negatip & $\begin{array}{l}\text { Non } \\
\text { motil }\end{array}$ & Positive \\
\hline P5 & Translucent & $\begin{array}{c}\text { Smooth } \\
\text { dull }\end{array}$ & White & Irregular & Raised & Entire & $\begin{array}{l}\text { Mono- } \\
\text { coccus }\end{array}$ & Negatip & Motil & Positive \\
\hline P6 & Opaque & $\begin{array}{c}\text { Smooth } \\
\text { shiny }\end{array}$ & White & Circular & Convex & Entire & $\begin{array}{l}\text { Staphy- } \\
\text { lococ-cus }\end{array}$ & Positive & Motil & Positive \\
\hline $\mathrm{P} 7$ & Translucent & $\begin{array}{c}\text { Smooth } \\
\text { shiny }\end{array}$ & White & Rhizoid & Raised & Filamentous & $\begin{array}{l}\text { Mono- } \\
\text { coccus }\end{array}$ & Positive & $\begin{array}{l}\text { Non } \\
\text { motil }\end{array}$ & Positive \\
\hline P8 & Translucent & $\begin{array}{c}\text { Smooth } \\
\text { shiny }\end{array}$ & White & Rhizoid & Raised & Erote & $\begin{array}{l}\text { Mono- } \\
\text { bacillus }\end{array}$ & Positive & $\begin{array}{l}\text { Non } \\
\text { motil }\end{array}$ & Positive \\
\hline
\end{tabular}

